\title{
The Protection of Fashion Shows: An Uncharted Stage
}

\author{
Elena Varese * and Valentina Mazza * \\ Intellectual Property and Technology Department, DLA Piper, 20123 Milan, Italy \\ * Correspondence: elena.varese@dlapiper.com (E.V.); valentina.mazza@dlapiper.com (V.M.)
}

Received: 27 August 2019; Accepted: 12 November 2019; Published: 17 November 2019

\begin{abstract}
The history of fashion shows goes back more than a century, and over the years, catwalks have gone from being private sales channels for a few wealthy customers to pure entertainment shows promoted globally. In this article, we analyze both national and international laws dealing with the protection of fashion shows in order to establish how fashion shows could be protected under intellectual property laws in Italy, with specific regard to copyright. The possibility for fashion shows to access copyright protection opens up a list of interesting questions: Who is the author of the work? Are models to be considered as performers? This scenario gets even more complicated if we consider how fashion shows have been changing in the last few years, turning to new technologies such as holograms, augmented reality, and drones. Further, copyright protection could be accompanied by further tools, such as registered or unregistered designs for the single elements of a scene and choreography or unfair competition if the general look and feel of a former fashion show has been slavishly imitated. A final section of this article is dedicated to the use of cultural heritage and historical museums, which are increasingly chosen by fashion houses for the settings of their shows.
\end{abstract}

Keywords: fashion shows; fashion law; copyright; performers' rights; collective works

\section{Introduction}

Fashion shows today are far more than just a couple of models on a catwalk. They include real stories and performances and entail very significant investments and the participation of a great deal of contributors. Examples vary from Fendi's iconic defile on the water of the Trevi Fountain in Rome or Louis Vuitton's carousel in black feathers and laces or, lately, Gucci's disruptive set of a hospital operating room, including models walking with sculptures of their own severed heads.

In this article, we move from a comparative perspective in order to analyze how France and the United Kingdom (UK) have dealt with the legal protection of fashion shows and how such creations could be protected in Italy, where it is still an unexplored matter. France, where the legal framework is similar to that of Italy, was the first country to take a position in relation to the legal protection of fashion shows in the leading Ashby case in 2008. Besides France, the UK is the only other country in the European Union (EU) where scholars have engaged in academic research on the issue. Therefore, for the purposes of this article, in order to come up with a possible regime of protection for Italy, we limited our research to the UK and France, which are not so far from Italy when it comes to the fashion industry.

The possibility for fashion shows to access copyright protection opens up a list of interesting questions: Who is the author of the work? Are models to be considered as performers?

In this article, we aim to answer these questions and to suggest how fashion houses should protect their rights in order to ensure that they can fully exploit what is often a multi-million-dollar investment. In doing so, we will also consider how new technologies and artificial intelligence are reshaping the fashion industry.

In particular, we will argue that, given the uncertainty of Italian law in applying the composite or collective work regimes to fashion shows and consequently identifying their author, if a fashion house 
wants to acquire intellectual property rights in a show, it should ensure the transfer of all the economic rights in the show, not only by the director, but also by all the relevant contributors.

As to the second question, because international treaties, such as the Rome Convention and the 1996 WIPO Performances and Phonograms Treaty (WPPT), define protected performances as those that are interpretations of a copyrighted work, we conclude that performers' rights should be extended to runway models as a matter of compliance with international law. Models have traditionally been ignored by policymakers, and despite being the protagonists of the catwalk, they have remained in the shadows when it comes to legal protection. However, the Copyright Directive (EU) 2019/790 on copyright and related rights in the digital single market has recognized the need to set up a more solid and protective set of rules for the benefit of performers.

Therefore, countries should no longer ignore their obligations and should take appropriate steps to ensure that models enjoy adequate protection. Fashion is currently going in a more sustainable and ethical direction. Many campaigns have focused on models' health issues, but fashion companies also have a legal and moral obligation to provide them with fair remuneration.

\section{EU Countries Dealing with Fashion Show Protection}

\subsection{France and the Leading Case: Ashby}

France, where the legal framework is similar to that of Italy, was the first country to take a position in relation to the legal protection of fashion shows. In particular, Article L. 112-1 of the French Intellectual Property Code provides that all works of the mind are protected regardless of their gender, form of expression, merit, or purpose, provided that they are original. Further, Article L. 112-2 enumerates a non-exhaustive list of copyrightable works. As to the specific issue of fashion shows, based on the provisions above in the case Ashby $v$ Gaulme, Kenzo et Lacroix, the French Supreme Court opened up a new path in the fashion law system, holding that fashion shows can be protected by copyright ${ }^{1}$. The suit for copyright infringement, not only with respect to the clothes, but also with respect to the fashion shows themselves, was brought by the French Federation of Couture and five haute couture companies (including Chanel, Christian Dior, and Hermes) against three photographers, who uploaded photographs as well as videos of the fashion shows in question on a website ${ }^{2}$.

In fact, the French Federation of Couture developed a strict system in order to monitor the use of photographs taken during fashion shows, whereby only photographers indicated by press organizations, which had agreed to standard contract terms, were allowed to use the photographs and only for information purposes, with express exclusion of any commercial purposes.

Ashby Donald and the other two photographers claimed that they were allowed to upload the photographs on the internet for the purposes of reporting current events under Article L. 122-5, No. 9 of the French Intellectual Property Code as well as under Article 10 ("Freedom of Expression") of the European Convention on Human Rights. Under these provisions, the author of a copyrighted work cannot prevent the reproduction or communication to the public, in whole or in part, of a graphic, architectural, or artistic work in written, audiovisual, or online forms for the exclusive purpose of immediately informing the public, as long as the author's name is clearly indicated.

Based on this exception, the photographers were found not liable at the first instance, but the Paris Court of Appeal reversed the decision and held that the photographers had engaged in copyright infringement, not only of the claimants' clothes, but also of the fashion shows themselves. The photographers appealed the decision to the French Court de Cassation, but the action was dismissed. Therefore, they decided to bring their case to the European Court of Human Rights (ECHR) in Strasbourg for the alleged violation of their freedom of expression.

Ashby v Gaulme, Kenzo et Lacroix, French Court of Cassation, 5 February 2008.

2 Ashby $v$ Gaulme, Kenzo et Lacroix, Court of Appeal of Paris, 13e chambre, 17 January 2007. 
According to the ECHR, the exercise of the freedoms envisaged by Article 10 of the European Convention on Human Rights is subject to duties and responsibilities and may also be subject to formalities, conditions, restrictions, or penalties only to the extent that they are prescribed by law and are necessary in a democratic society ${ }^{3}$.

As some photographs were available for online download only upon payment and the photographers' commercial purpose was thus evident, the French Court of Appeal and the ECHR denied the application of the exception of freedom of expression and found the defendants liable for copyright infringement, pursuant to Articles L 335-2 and 3 of the Code de la Propriété Intellectuelle.

\subsection{The UK and the Broad Interpretation of the Copyright, Designs, and Patents Act (CDPA)}

Following the Ashby decisions, discussions on the eligibility of fashion shows for copyright protection have also taken place in the $\mathrm{UK}^{4}$.

Unlike the legal framework of Italy and France, the UK Copyright, Designs, and Patents Act 1988 requires fixation for a work to access copyright protection. However, this is not an obstacle, because fashion shows can be captured through audio-video recording or photographs.

Another difference in the civil law systems is that the CDPA does not provide for an open-ended list of copyrightable works. Therefore, under UK law, the main issue is to establish whether fashion shows may fit within the categories of protectable works set by section 3(1) of the CDPA.

Indeed, section 3(1) of the CDPA can be interpreted to include fashion shows within the two categories of "dramatic works" or "choreographic works". With respect to dramatic works, it can be argued that the very essence of fashion shows is to be performed by models walking down the runway and that, together, they hold sufficient dramatic unity to satisfy the relatively low threshold set by the UK case law, which merely requires that the substance of the work is not left to chance or mere randomness ${ }^{5}$.

As an alternative interpretation, the clothing, directing, and staging of models may be considered as a form of choreography, because models have to walk in a certain order, presumably wearing a series of similar clothes in a first round, followed by another series in a second round, and so on.

A similar reasoning has already been followed by UK courts in relation to "aesthetic" or "choreographed" sports, such as cheerleading, synchronized swimming, figure skating, acrobatic gymnastics, ice dancing, and wrestling. In particular, the courts distinguished such choreographed sports from more traditional "adversarial" sports, such as football, baseball, basketball, cricket, and hockey, on the grounds that the former present a repetition of basic individual movements, i.e., a sort of plot. Therefore, given their low margin of improvisation and unpredictability and the fact that they are not affected by the movements of the adversarial players, UK courts have recognized the repetitive and choreographic nature of "aesthetic" sports and decided for their copyrightability".

Therefore, even if there is some criticism against the inclusion of fashion shows within the definitions of copyrightable subject matter under the CDPA, we believe that there is room to argue that they may also be protected by copyright under UK law, falling within the category of dramatic or choreographic works.

\footnotetext{
Ashby Donald v France, App No. 36769/08, ECHR, 10 January 2013.

(Derclaye 2008); see also (Pavis 2018c).

Norowzian v Arks Ltd (No 2) [2000] EMLR 67; The Ukulele Orchestra of Great Britain v Erwin Clausen and another (t/a the United Kingdom Ukulele Orchestra) [2015] EWHC 1772 (IPEC); Banner Universal Motion Pictures Ltd v Endemol Shine Group Ltd [2017] EWHC 2600 (Ch); Green v Broadcasting Corp of New Zealand [1989] RPC 469, applied in Robin George Le Strange Meakin v British Broadcasting Corporation and others [2010] EWHC 2065 (Ch) paras 29-31 (Arnold J).

6 See https://www.entsportslawjournal.com/articles/10.16997/eslj.1/\#targetText=In\%20Norowzian\%20v\%20Arks\%20Ltd, being\%20performed\%20before\%20an\%20audience.
} 


\subsection{Possibility of Protecting Fashion Shows in Italy through Copyright}

Fashion shows at Milan Fashion Week are becoming a true experience, with scenic effects often taking place in historic locations. The sets are more and more complex and involve the work of architects and artists, who are asked to create extraordinary and multi-sensorial shows, where everything, such as lights, sounds, and colors, has to be studied in detail.

Fashion shows today are no longer the mere presentation of the designer's latest creation; rather, they have become a cultural phenomenon-a means of expression of artistic, social, historical, and sometimes political values. Let us think, for instance, about Missoni, dressing models in pink caps as a symbol against female discrimination, the echo of Queen Elizabeth's first time sitting in the front row of a fashion show next to the legendary Vogue Editor-in-Chief Ann Wintour or Valentino Garavani's three-day spectacular farewell to the catwalks in Rome to celebrate his 45-year-long relationship with the Eternal City, etc. ${ }^{7}$.

Yet, in Italy, no reported case has ever dealt with how fashion shows could be legally protected. The issue is not irrelevant, given —on the one hand-the high investment made for the setting up of the show, which justifies protection against imitation as soon as the work is created, and-on the other hand-the possibility of reproducing fashion shows through audiovisual means and photographs, at a later stage. Therefore, after a comparative analysis of the French and UK legal systems as described above, we will now consider the main factors in favor and against the copyright protection of fashion shows in Italy.

Some policy considerations against the copyright protection of fashion shows could be that they are ancillary to the sale of a product (i.e., the last collection of garments created by the fashion maison) and therefore do not present a sufficient degree of originality. Yet, the ultimate aim to trigger an economic advantage to the creator or its assignees should not be taken into account to prove copyright protection, as shown, for instance, by the fact that advertising creations are protectable in Italy as autonomous works of art. Thus, under Italian law, copyright should exist insofar as the concerned work is original, without taking into account its ultimate purpose. Further, originality merely requests that the work carries out an expression of the author's personality, without entering into the merits of the creation.

It is, therefore, reasonable to argue that the majority of modern fashion shows might present a sufficient degree of originality to access copyright protection in the Italian system, insofar as they bring together a combination of scenic and technical solutions, music, costumes, and settings.

From a purely legal perspective, a second objection might be that fashion shows are a sort of "volatile" creation that is displayed once and for all and would be incapable of being repeated over time, as they have no sufficient unity and definition, which are requirements that are often difficult to prove, for example, in the case of formats. In this regard, the Italian case law traditionally granted protection as formats to works that presented a given number of fixed elements, including scenes, characters, and narrative solutions. For instance, the Italian Supreme Court, in its decision No. 18633 of 27 July $2017^{8}$, granted copyright protection to formats, provided that they presented "a basic scheme identifying the main characteristic features of a TV show or, more often, of a whole series of truly coordinated episodes". Such features have been identified in the "main structural elements of the story, the setting in an identified time and space, the common thread of the narration and the characters in their peculiarities". For this reason, the protection of fashion shows as formats might present issues, as there might not be a sufficient repetition and definition of fixed elements, given the limited length of the show and the fact that it is not divided into episodes.

7 For an overview of the 100 most spectacular fashion shows from the ' 60 s to date see https://www.iodonna.it/moda/news/ 2019/02/19/sfilate-momenti-memorabili/.

8 Available in the database http://cassazione.net/. 
Considering, however, that modern fashion shows have more often an actual directorship and plot and could be theoretically repeated, they can be said to have a sufficient unity of definition. In one of the most recent and illustrative cases, the Dolce \& Gabbana AI 2020 show in the Valley of the Temples, Sicily, was directed by the Oscar-winning filmmaker Giuseppe Tornatore, who created what the press defined as a "couture mythology" atmosphere, with models walking around the ruins similar to the Greek muses of the ancient myths".

Further, copyright protection is granted also to creations that might vary over time within the lines of a given plot (this is the case, for instance, for performance arts). Unlike other legal systems, such as that of the United States, fixation is not a requirement to access copyright under Italian law, which protects oral works or works that cannot be repeated. In this regard, performance arts, rather than choreographic works, seem to be the most akin creation to fashion shows. On the one hand, and as an exception to the general rule, choreographic works request a certain degree of fixation of the main lines of the work, as provided by Article 2, paragraph 3 of the Law of 22 April 1941, No. 633 Italian Copyright Law (ICL). Such fixation is requested in writing or through audiovisual means and might be, in some cases, a potential obstacle for the assimilation of fashion shows to choreographic works.

On the other hand, performance arts do not require the fixation of the plot and theoretically allow a wider degree of discretion and variation, depending also on social and environmental factors.

Overall, it is not necessary to justify the protection of fashion shows through copyright by making such creations fall within the listed categories of protected works. In fact, the conclusive argument to allow the protection of fashion shows in the Italian system is that Article 2, paragraph 3 of the ICL grants protection to different kinds of creative works and-different from other legal systems such as the UK-provides for an open-ended list of copyrightable works, insofar as they are sufficiently original.

This has already paved the way in other jurisdictions to discuss the extension of copyright protection to other subject matters relevant to the fashion system, such as the debated case of perfumes ${ }^{10}$.

Thus, under Italian law, fashion shows might well account for an autonomous copyrightable work (albeit not expressly named by the ICL), as long as they meet the originality threshold provided by the ICL, which is, traditionally, not particularly high.

\section{Who Is the Author?}

Once ascertained that fashion shows can be protected by copyright, the next question is who is the copyright owner of the work?

Fashion shows are the result of the work of a number of contributors, including architects, set designers, sound and light technicians, hairdressers, makeup artists, seamstresses, etc.

The question of authorship of fashion shows is controversial, as they might fall under at least two different regimes provided by the ICL for works made by more than one contributor.

In a first scenario, fashion shows might fall within the category of "composite works", as their various parts cannot be separable, as opposed to works whose components are formed by distinct and reciprocally autonomous contributions. In this case, Article 10(1) of the ICL will apply, and copyright will be vested in each coauthor of the components falling within the communion regime. Thus, unless differently provided in writing, each coauthor is free to use autonomously the component that he has devised.

According to a second interpretation, fashion shows might fall within the category of "collective works", defined as the union of works or parts of works by different authors that are autonomous creations, brought together as a result of choice and coordination for a given literary, scientific, educational, religious, political, or artistic purpose. Collective works exist regardless of the separability

9 See https://www.vogue.it/moda/article/dolce-and-gabbana-agrigento-sfilata-alta-moda-tempio-della-concordia.

10 Kecofa/Lancôme, Dutch High Court, HR, June 16; 2006, LJN AU8940; Thierry Mugler Parfums c/GLB Molinard, Tribunal de commerce de Paris (1999); Société Bellure/SA L'Oréal et al., Cour d'appel de Paris, 25 January 2006. 
of their respective components. Classic examples of collective works are encyclopedias, anthologies, magazines, and movies. Under Article 7 of the ICL, the author of the collective work is considered to be whoever organizes and directs the creation of the work itself. In our case, and given their increasing complexity and spectacularism, the coordination of the different components of the fashion show is often managed by an external director specifically appointed by the fashion house to devise the show and supervise its development. Such director would likely be considered to be the author of the fashion show, if we consider the latter to be a collective work.

Therefore, given the uncertainty in applying the composite or collective work regimes, if the fashion house wants to acquire the intellectual property rights to a fashion show, it should ensure the transfer of all the economic rights of the show, not only by the director, but also by all the relevant contributors (including the creators of the original music and scenography).

However, it should be noted that under Italian law, only economic rights in a copyrighted work can be transferred, whereas moral rights will remain vested in the different contributors, who will keep the right to be indicated as the authors of their respective works.

\section{Can Models Be Considered Performers?}

Since both national and international law define protected performances as those that are the interpretations of a copyrighted work, this would include the performance of a fashion show by runway models.

In this regard, Article 80(1) of the ICL considers acting and performing artists to be "actors, singers, musicians, dancers, and other persons who perform, sing, act, recite, or in any way execute intellectual works, should this be protected or of public domain". Similarly, Article 3(b) of the Rome Convention and Article 2(b) of the 1996 WIPO Performances and Phonograms Treaty provide protection to "actors, singers, musicians, dancers, and other persons who act, sing, deliver, declaim, play in, or otherwise perform literary or artistic works", mirroring the classification of copyrightable subject matter provided by the Berne Convention for the Protection of Literary and Artistic Works. In addition, the Beijing Treaty on Audiovisual Performances of 2012, dealing with the intellectual property rights of performers in audiovisual performances, grants performers economic and moral rights with specific reference to unfixed (live) performances ${ }^{11}$.

If we read international treaties as conferring performers' rights to anyone who interprets a "work" within the meaning of copyright law, such protection should be extended to runway models as a matter of compliance with international law ${ }^{12}$.

Further, another level of interpretation considers the Rome Convention and the WPPT to establish a de minimis standard of protection, where protected performances would be, at a minimum, those that are interpretations of protected or protectable works under copyright law.

This interpretation is supported by Article 9 of the Rome Convention, which specifies that "[a]ny Contracting State may, by its domestic laws and regulations, extend the protection provided for in this Convention to artists who do not perform literary or artistic works", so implying that the existence of a copyrighted work underlying the performance is central to the definition of protected performers under Article 3(a).

11 The Beijing Treaty on Audiovisual Performances was adopted by the Diplomatic Conference on the Protection of Audiovisual Performances, which took place in Beijing from 20 to 26 June 2012. As to unfixed (live) performances, the treaty grants performers three kinds of economic rights: (i) the right of broadcasting (except in the case of rebroadcasting); (ii) the right of communication to the public (except where the performance is a broadcast performance); and (iii) the right of fixation. With respect to moral rights, they include the right to claim to be identified as the performer (except where such an omission would be dictated by the manner of the use of the performance) and the right to object to any distortion, mutilation, or other modification that would be prejudicial to the performer's reputation, taking into account the nature of the audiovisual fixations.

12 See (Pavis 2018a, 2018b). See also (Pavis 2019). 
Consequently, national laws may depart from the Rome Convention only to the extent that they provide a more generous standard of protection than that granted under the international agreement, but they cannot deny performance rights with respect to copyrighted works. Failure to do so would place signatory countries in breach of their international obligations. Therefore, as far as fashion shows are to be considered as protectable subject matter in Italy, performers' rights could be granted to models who "execute" the fashion show through a given number of movements in an assigned timing.

It is, however, to be seen if, in order to access protection as a neighboring right, models walking down the catwalk will be deemed to play a role of "remarkable artistic importance", as requested by Article 82(1) of the ICL to acting and performing artists of literary, dramatic, and music works. One argument could exclude this threshold, as fashion shows might fall within the category of artistic works and not within those expressly listed by Article 82(1) of the ICL. On the other hand, it would be unfair to impose a lower requirement to access neighboring right protection to models as opposed to other categories of performers. Thus, it would be reasonable to protect the performance of models within fashion shows insofar as they cover a role of "remarkable artistic importance", which is not such an higher threshold, especially in light of the length and level of elaboration of modern fashion shows.

The recognition of performers' rights to fashion models represents a significant step ahead towards the protection of their category, which has traditionally been neglected by policymakers.

First, these intellectual property rights guarantee models adequate remuneration by conferring the right to control and monetize the fixation and distribution of their performance on the runway. In fact, runway models are increasingly becoming protagonists of the fashion system and can now be found within other forms of productions with clear distribution lines and extended commercial longevity, as the many related dedicated TV shows demonstrate ${ }^{13}$. Second, performers' rights confer protection in the form of moral rights, i.e., the rights to protect the integrity of their performance and to ensure that they are given credit for it. Thirdly, because performers' rights may be enforced collectively through representative organizations, they would eventually give models' unions significant leverage in negotiations with other players in the industry.

The need to set up a more solid and protective set of rules for the benefit of performers has also been recently recognized by the Copyright Directive (EU) 2019/790 on copyright and related rights in the digital single market, which warns that "performers tend to be in the weaker contractual position when they grant a license or transfer their rights, including through their own companies, for the purposes of exploitation in return for remuneration" (Whereas 72). In fact, Article 18 of the New Copyright Directive provides that " $[\mathrm{m}] \mathrm{ember}$ States shall ensure that where authors and performers license or transfer their exclusive rights for the exploitation of their works or other subject matter, they are entitled to receive appropriate and proportionate remuneration". In addition, Article 19 lists a series of transparency obligations for the performers' counterparties in order to ensure that they are made aware of the modes of exploitation of all revenues generated and of the remuneration due for their works.

Although this is not enforceable law and it is up to the member states to implement the obligations set forth in the New Copyright Directive, we believe that if the New Copyright Directive dedicates two provisions to the protection of performers' rights, this is proof that performers' rights should be awarded to anyone who interprets a "work" within the meaning of copyright law.

\section{The Impact of New Technologies}

The above background gets even more complicated if we consider how fashion shows have been changing in the last few years, turning to new technologies such as holograms, augmented reality, and drones.

13 See for example the TV shows "Project Runway", "The Face", and "Make Me a Supermodel" based on fashion designing and runway modeling performances. 
In New York, Intel partnered with numerous designers, including Erin Fetherston, Prabal Gurung, and Band of Outsiders, to live broadcast their shows in virtual reality. Similarly, the London-based fast fashion retailer Topshop provided shoppers with headsets, enabling them to see its catwalk show in real-time through a three-dimensional (3D) virtual world.

Designer Rebecca Minkoff, meanwhile, turned to augmented reality via a partnership with shopping app Zeekit, which allowed viewers to upload a picture of themselves to see what they would look like in their favorite items following the show.

One of the most interesting innovations, however, came in the mixed reality space. This time, it was not so much about capturing and replicating an experience to transport users but, rather, creating an experience layered over the real world through holograms. This was used on a runway for the first time by the legendary Alexander Mc Queen back in 2006, when a hologram version of Kate Moss modeled a dramatic organza gown. Holograms have recently appeared in the fashion shows of Diesel, Guess, and Ralph Lauren, creating optical illusions and taking the relationship between fashion and technology to the next level.

Lastly, during a recent fashion show in Milan last February, luxury designers Dolce \& Gabbana did not trot out handbags on the arms of slender humans. Instead, drones did the heavy lifting, emerging from backstage to the cheers of the audience, capturing it all on smartphones.

The impact of new technologies on fashion shows opens up a set of unanswered questions. Are models to be replaced by holograms and drones? Could holograms and drones be considered performers? Who is the author of the collective work created by artificial intelligence?

The starting point of the discussion on the copyright protection of creations of artificial intelligence (AI) — which could also involve fashion shows taking place in augmented reality and created by AI-is that, under Italian law, creative works must be original to get copyright protection, and traditionally, the requirement of originality has been linked to the physical person of the author. In fact, under Article 6 of the ICL, "the original entitlement of the acquisition of copyright consists of the creation of the work, as a particular expression of intellectual work of the author". Therefore, machines and AI seem to be excluded from the notion of authorship. However, this does not mean that algorithmic artworks cannot afford copyright protection, as long as human choices are involved ${ }^{14}$.

Because the revolution of artificial intelligence is affecting almost every field and it is currently at the center of some legislative studies, we believe it will not be too long for this issue to come before national courts.

\section{Location Matters: Use of Artistic Monuments}

Given the bigger role played by artistic monuments and museums in recent fashion weeks, a special section of this article is dedicated to the historic monuments and artistic and architectural works used as sets of fashion shows ${ }^{15}$.

In fact, from the Louvre Museum for Louis Vuitton, the Tour Eiffel for Yves Saint Lauren, the Valley of Temples for Dolce \& Gabbana, and the Capitoline Museums in Rome for Gucci, fashion houses continue to choose iconic monuments of relevant cities for their catwalks.

Under Italian law, pictures of historic monuments, artistic and architectural works, buildings and, generally speaking, all works that have a cultural value are subject to a specific legal regime.

In fact, even when such works are no longer covered by copyright protection, the Italian Code on Cultural Heritage and Landscape (Legislative Decree No. 42/2004-Codice dei beni culturali e del paesaggio) also applies.

14 For a discussion on the relationship between artificial intelligence and copyright, see, among others, http://www.caaai.eu/ wp-content/uploads/2012/08/MdeCockBuning-Copyright-and-robotisc-robotics-law-journal_03_november_2015.pdf.

15 https://blogs.dlapiper.com/iptitaly/2018/10/fashion-runways-and-right-of-panorama-a-trendy-combo/. 
More specifically, Articles 107 and 108 of such law require those who want to use pictures reproducing goods that belong to Italian cultural heritage to seek authorization from the authority that possesses it, which can either be the state or a local public entity. In any event, once the authorization is granted, a fee must be paid to the relevant authority. There is not a fixed fee to be paid but, rather, is determined by each authority depending on the kind of use to be made.

Exceptions to this rule are limited and could be included in the so-called "right of panorama", that is "the freedom to photographically reproduce monuments, artistic and architectural works, buildings and any public space in general without infringing third parties copyrights on such goods".

Although, under Italian law, the right of panorama exception is more limited than in other EU countries, the Article 108 mentioned above provides that no authorization and no fee are due for the reproduction of such works (a) by individuals in the case of personal use or for study purposes; (b) by private or public subjects for the purpose of enhancement, provided that they are implemented without profit; or (c) in the case of non-profit activities, study, research, manifestation of thought, or creative expression and promotion of cultural heritage.

Therefore, with respect to the right of panorama, a distinction shall be made between the fashion house hosting the show and the guests and journalists posting pictures of the runway.

In fact, the exception applies only to the personal use of the latter groups, who are free to publish images of the models and of the historic monuments and artistic and architectural works used as the sets of such shows.

Use of such works by the maison hosting the catwalk is, instead, made for commercial purposes and thus requires it to seek authorization from the competent authority and pay the relevant fees. The same is also true for press campaigns, tv spots, and any other commercial use made by the fashion brands with respect to historic monuments, artistic and architectural works, buildings and, generally speaking, all works that have a cultural value.

\section{Conclusions}

This work builds on the extension of copyright protection to fashion shows to answer three questions that are crucial in the fashion industry: Are fashion shows copyrightable subject matter? Who is the copyright owner of the work? Are models considered performers?

As to the first question, fashion shows can be protected under copyright in Italy, as there is not a fixation requirement for copyright works nor is there a closed catalogue of copyright subject matter. In this respect, the most akin creations to fashion shows are performance arts, which allow the repetition of a given plot but are also subject to a certain degree of variation, influenced by environmental and social conditions.

Regarding the second question, fashion shows fall within the category of "collective works" and, although they are the result of the work of a number of contributors (architects, set designers, sound and light technicians, hairdressers, makeup artists, seamstresses, etc.), the author has to be considered the director, who is in charge of devising and organizing such work. Typically, fashion maisons appoint well-known art directors to create and coordinate fashion shows.

With respect to the role of models, international laws set a minimum standard whereby as long as a performance is the interpretation of a copyrighted work, performers' rights shall apply. It is reasonable to argue that the performance of the model in the context of the fashion show involves a role of "remarkable artistic importance", thus warranting protection by neighboring rights. Therefore, if this is the case, and once it is established that fashion shows enjoy copyright protection, countries denying performer rights to models walking down the catwalk might theoretically be in breach of their international obligations.

To be on the safest side, fashion companies should include in their agreements a clause whereby all the relevant individuals, including fashion directors and models, transfer their economic rights as authors, coauthors, and performers of the fashion show. 
Finally, copyright protection could be accompanied by further tools, such as registered or unregistered designs for the single elements of a scene or choreography or unfair competition, if the general look and feel of a former fashion shows has been slavishly imitated.

Author Contributions: Writing—original draft, E.V. and V.M.

Funding: This research received no external funding.

Conflicts of Interest: The authors declare no conflict of interest.

\section{References}

Derclaye, Estelle. 2008. French Supreme Court rules fashion shows protected by copyright-what about the UK? Journal of Intellectual Property Law \& Practice 3: 286-7.

Pavis, Mathilde. 2018a. If Runway Models Are Performers ... Is France in Breach of Its International Obligations? Available online: http://ipkitten.blogspot.com/2018/07/if-runway-models-are-performersis.html (accessed on 10 August 2019).

Pavis, Mathilde. 2018b. Runway Models Are Not Performers. Are You Sure? Available online: http://ipkitten. blogspot.com/2018/07/runway-models-are-not-performers-are.html (accessed on 10 August 2019).

Pavis, Mathilde. 2018c. Runway models, runway performers? Unravelling the Ashby jurisprudence under UK law. Journal of Intellectual Property Law \& Practice 13: 867-77.

Pavis, Mathilde. 2019. "In Fashion, One Day You Are in, the Next You Are out": Comparative Perspectives on the Exclusion of Fashion Models from Performers' Rights. Cairo: EIPR, vol. 41. 